\title{
Discourse Markers in Tertiary Level Students' Essay Writing: Ability and Problems
}

\author{
Winny Agustia Riznanda \\ Universitas Islam Negeri Raden Fatah Palembang \\ winnyagustiariznanda_uin@radenfatah.ac.id
}

\begin{abstract}
Writing is a fundamental, yet complicated part of language learning. In writing, Discourse Markers is an indispensable component of writing quality. The aim of the present study was to find out how Discourse Markers (DM) were applied to build coherence in EFL students' essay writing and the problems encountered. Descriptive design was applied; analyzed 52 target DM and how they were used in 30 academic essay writing. The participants of the study were 30 students majoring in English Education of UIN Raden Fatah Palembang academic year 2019/2020. The results revealed that the participants employ $32 \mathrm{DM}$ in 221 occurrences, in which 102 occurrences were inappropriately used. The problematic matters cover non-equivalent exchange (52 occurrences), and overuse (48 occurrences). Despite their awareness of the importance of DM to assure the coherence of their essays, they need to develop their ability to use DM correctly and efficiently to make their writing connected more logically.
\end{abstract}

Keywords: discourse markers, coherence, essays.

\section{INTRODUCTION}

Writing is an essential language skill to be mastered. Writing, according to Defazio, Jones, Tennat, and Hook (2010), is essential since it involves students' thinking, and presents students' creativity and understanding. Furthermore, they claimed that writing is a skill needed to determine students' accomplishment during their study since the students must be able to complete tasks of writing, such as academic

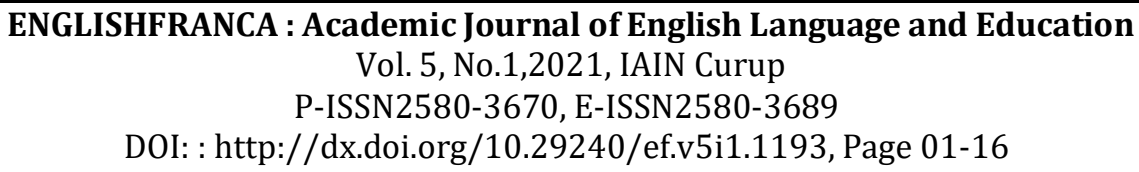


essays and papers. Essays are used to examine your grasp of certain topics as well as your ability to explain and debate these concepts in order to answer a specified topic. An essay is often written in prose, in a discursive style, in which the concept, arguments, and evidence are presented to answer a question or solve a problem (Oktavianti et al, 2020). Writing ability is generally the least devoted to learners. The fact that productive development of the writing skill is impacted by successful acquisition of other skills also proves that writing is the most difficult talent in English (Sanjaya et al, 2020). Furthermore, when the students started working, writing job application letters, e-mails, proposals, reports, and memos are required as part of professional communication.

Despite its importance, writing is a complex language skill. Oshima and Hogue (2006) argued that writing requires mastery of various components, namely content, organization, use of language, vocabulary, and mechanics. Furthermore, Richards and Renandya (2002) added that most ESL/EFL students found difficulties in planning and structuring their ideas and convert them into text. In addition, Indonesian students' writing attitude is required to be considered. Research conducted by Setyowati and Sukmawan (2016) revealed that fifty-eight percent (out of fifty-seven) EFL students showed a moderate attitude towards writing, but stated that writing was difficult and stressful.

A preliminary study was carried out through interviews and observations of students of the English Education of UIN Raden Fatah Palembang of 2019/2020. It was found that most students were unable to produce essays that meet the requirements due to their poor academic writing skills, particularly in the development of ideas. In addition, language features such as connectors were not used accurately which caused the sentences in the essays to be less related to one another. This was due to the lack of students' knowledge regarding essay writing coherence.

One of the fundamental problems that students face in writing is the relationship between sentences, also known as cohesion. Students, according to Oshima and Hogue (2006), must consider an important feature in writing texts, namely coherence, so that each sentence in the essay is related to one another. Furthermore, Kellog (2008) explains that coherence writing is intricate. This is because literacy is an accomplishment in a culture that has never been studied in depth. 
Winny Agustia Riznanda: Discourse Markers in Tertiary Level Students' Essay Writing: Ability and Problems $\mid 3$

Brown (2007) added that to produce coherent writing, students must consider a variety of factors, including how to create concepts, structure them sequentially, and use Discourse Markers.

Researchers agree on the importance of DM to improve coherence in writing. The presence of DM, such as: however, accordingly, and for example can contribute to text coherence (Tyler \& Bro 1992, Muller 2004). Furthermore, Swan (2005) defined DM as a word and expression that connects what we are conveying, what we have delivered, and what will be conveyed. Moreover, Fraser (1999) describes that DM interprets semantic relations between discourse units without altering the semantic relationships between them. In other words, DM is words or phrases, conjunctions, adverbs, or prepositional phrases that indicate the relationship between the segments they introduce and the segments that came before them. In terms of writing, correct DM usage assists the writer in producing productive documents. The presence of DM in written language is similar to the presence of gestures in spoken language; it demonstrates the writer's understanding in organizing texts by marking the development of their arguments and directing the reader towards interpretations that the author prefers (Biber, Johansson, Leech, Conrad \& Finegan, 1999; Celce-Murcia \& Larsen Freeman, 1999).

DM and writing have become interesting research subjects. Studies conducted by Liu and Braine (2005), Jalilifar (2008), and Rahimi (2011) investigated how ESL/EFL students apply DM in their writing. Studies conducted by Field and Yip (1992), Johnson (1992), and Hinkel (2001) proposed the native use of DM differs from the non-native use of DM. In addition, Connor (1984, 2000), Castro (2004), and Jalilifar (2008) claimed that correct use of DM improves the quality of written works.

However, some studies have shown that applying DM for second language and foreign-language learners is complicated. Studies conducted by Cho (1998), Bolton, Nelson, and Hung (2002), Narita, Sato, and Sugiura (2004) reported difficulties encountered by L2 students, such as abuse, overuse, and underutilization of DM. Furthermore, studies conducted by Kao and Chen (2011) proposed six problems encountered by Taiwanese students, namely: non-equivalent exchange, overuse, surface logic, wrong relations, semantic inclusions, and disturbances. In Indonesia, a study conducted by Patriana, Rachmajanti, and Mukminatien (2016) which analyzed the use of 21 students' 
argumentative markers of argumentative essays by Indonesian students found that in 234 occurrences, 118 occurrences used DM improperly.

Therefore, the problems in this study are: (1) What discourse markers (DM) are used by English Education students to build coherence in their essay writing? (2) What problems do students of English Education have in applying discourse markers (DM) in their essay writing?

\section{THEORETICAL FRAMEWORK}

Linguists define DM distinctively depending on their research and subject areas. Halliday and Hasan (1976) use the term sentence connectors, Blakemore (1987) uses the term discourse connectives or Fraser (1999) uses the term pragmatic markers. Swan (2005) defines DM as words and expressions that are used to depict the organization of our conversation. Their function is to connect what we are saying, what we have said, and what we will say in the future.

Writing with DM is preferable in some ways. DM provides arrangements due to the numerous words and phrases of DM available (Wei Sun, 2013). Furthermore, because of the segmentation provided by DM, readers, and listeners can stop and interpret linguistic signals. Although DM is optional, has no grammatical effects, and carries little semantic weight, removing them can create uncomfortable, less natural, ill-mannered, unfavorable interaction (Brinton, 1996). Moreover, Fraser (1999) claimed that the absence of DM may cause a breakdown in interaction.

\section{RESEARCH METHODOLOGY}

This study uses a descriptive research design which was conducted at the English Education of UIN Raden Fatah Palembang. The data source of this research is 30 essays written by students. The essay was analyzed in terms of 52 types of Discourse Markers (DM) coined by Fraser (1999).

Tabel 1.

Taxonomy of DM Adapted from Fraser (1999)

\begin{tabular}{l|l}
\hline Elaborative Markers & \\
\hline Additive Markers & $\begin{array}{l}\text { moreover, furthermore, in addition, } \\
\text { besides, additionally, likewise, }\end{array}$ \\
\hline
\end{tabular}


Winny Agustia Riznanda: Discourse Markers in Tertiary Level Students' Essay Writing: Ability and Problems $\mid 5$

\begin{tabular}{|c|c|}
\hline & similarly \\
\hline Appositive Markers & in other words, otherwise, that is \\
\hline Illustration Markers & for instance, for example \\
\hline Summative Markers & $\begin{array}{l}\text { in conclusion, in short, in brief, in } \\
\text { summary, to sum up }\end{array}$ \\
\hline \multicolumn{2}{|l|}{ Adversative Markers } \\
\hline Concessive Markers & however, but though, still, yet \\
\hline Corroborative Markers & indeed, in fact, of course \\
\hline Corrective Markers & on the contrary, instead, rather \\
\hline Contrastive Markers & $\begin{array}{l}\text { in contrast, on the other hand, by } \\
\text { contrast, conversely, alternatively }\end{array}$ \\
\hline Causal-Inferential Markers & $\begin{array}{l}\text { so, thus, therefore, then, (in) this way, } \\
\text { hence, in this case, in this respect, } \\
\text { consequently, as a consequence, as a } \\
\text { result, for this reason, accordingly }\end{array}$ \\
\hline
\end{tabular}

The researcher grouped each of the clauses found in the essays to provide a thorough analysis of the DM enclosed in each clause. Then, the researcher highlights all of the DM enclosed in each clause. Following that, the DM that have been highlighted are identified and grouped using Fraser's (1999) DM classification, which includes additive (appositive, illustration, summative), adversative (concessive, corroborative, corrective, contrastive), and causal-inferential markers. Next, DM contained in all essays was calculated and quantitatively described. Finally, three verifiers check the researcher's work to ensure that all of the descriptions are approved, preventing errors in data analysis.

\section{FINDINGS AND DISCUSSION}

FINDINGS

DM used in English Education Students' Essays

This study revealed that out of the 30 academic essays composed by the participants, 32 different DM were applied in 221 occurrences, 
196 of which were used at the beginning of a sentence and were always followed by commas. As a result, it can be assumed that the participants prefer to break complex sentences into simple sentences and only use $\mathrm{DM}$ at the beginning of the second section to signal a topic change. This DM use backs up McCarthy's (1993) assumption that DM shapes and expands discourse substance more effectively than conjunction.

Based on the taxonomy provided by Fraser (1999), it revealed that there were 221 occurrences of DM in 30 academic essays written by the participants. The number of occurrences of each taxonomy type was shown in the following table.

Table 2.

Categorization of DM on Participants' Essays

\begin{tabular}{|l|l|c|}
\hline No. & \multicolumn{1}{|c|}{ Types of DM } & Occurrences \\
\hline 1. & Adversative Markers & 82 \\
\hline 2. & Causal Inferential Markers & 71 \\
\hline 3. & Elaborative Markers & 68 \\
\hline
\end{tabular}

\section{Problems Encountered by English Education Students in Applying DM}

This research revealed that there are some problems with the use of DM found in participants' essays (in 221 occurrences). These problems are categorized into the non-equivalent exchange (38 occurrences) and overuse (32 occurrences).

To determine the source of the problem, a further exam on the participants' English writing skills was administered, revealing that the higher achievers use a broader variety of DM than the lower achievers. To avoid repeating the same DM, they use DM interchangeably. It can also be assumed that higher achievers use DM to improve the sophistication of their writing. Participants who are lower achievers, on the other hand, are more likely to use small groups of DM, which may cause by a lack of knowledge on other DM. In terms of the relationship between sentences, they prefer DM they are accustomed to when they are having difficulty in organizing arguments in their writing, which implies that they are having difficulty in organizing their arguments into coherent texts. 
Winny Agustia Riznanda: Discourse Markers in Tertiary Level Students' Essay Writing: Ability and Problems $\mid 7$

\section{Non-Equivalent Exchange Problem}

The problem of non-equivalent exchange is seen in the essay number 20 essay below:

"The greenhouse effect is caused by greenhouse gases produced by nature or human activity. Yet, many people did not realize this. "(essay number 20)

The example above presents the causes of greenhouse gases. In combining the first and second sentences, students use DM 'yet'. However, 'yet' is used for less formal equivalent and to illustrate unexpected information in the order of positive to negative. Therefore, the more correct DM for this example is 'however' to present problems.

\section{Overuse problem}

The overuse problem occurs when the relationship between sentences is so clear that it does not require DM, as demonstrated by the following essay by student number 12 :

"Can cyberbullies be forgiven? Shouldn't they be academically punished? Are there bullies, indeed, specifically the high education ones are unaware of the effects of bullying? "(essay number 12)

Students use the phrase "indeed" in essay number 12 to emphasize the question of whether students at the higher education level are aware of the consequences of engaging in cyberspace. Because students used 'specifically,' the use of DM 'indeed' is unnecessary, and the sentence is coherent without DM.

\section{DISCUSSION}

This study revealed that adversative and causal inferential markers are frequently used. This is due to the nature of the argumentative essays written by the participants. Adversative markers (such as however, in contrast, and on the other hand) are the most common because, when writing their argumentative essays, participants must indicate differences of opinion on some issues and anticipate ideas that are contradictory from the readers' perspective and seek to rebut them, as shown in essay number 21 : 
"Many humans are building things to reach the expectations of society to create a modernized civilization. However, humans build all these things despite the consequences and the effects to the environment such as pollution, deforestation, and the increase in the amount of trash. "(essay number 21)

The Causal Inferential Markers (such as thus, therefore, and hence) is assumed to be the need of students to build evidence for argumentative claims, as in the following essay number 3 :

"The causes of global climate are multifactorial, thus a systematic approach from government organizations and individuals is needed to tackle the issue." (essay number 3)

In addition, the presence of Additive Markers (such as furthermore, and in addition) show that they describe their ideas by providing additional information. Illustration Markers (such for instance and for example) are used to show examples, as in the following essay citation number 5 and 10:

"According to Europe.EU, $\mathrm{CO} 2$ is the most commonly produced by human activities and it is responsible for $64 \%$ of man-made global warming. This state proves that global warming is caused mostly by humans. Furthermore, the world's leading climate scientists believe that human activities are almost certainly the main cause of the warming observed since the middle of the 20th century. "(essay number 5)

"The earth is getting hotter because of humans activities. For example, humans open green areas such as forests, plantations, and replaced them with multistoried buildings, factories, housings, and others. "(essay number 10)

Furthermore, this study revealed that the participants encountered non-equivalent exchange and overuse problem in their essays. The non-equivalent exchange problem can be presumably rooted in how DM is presented at schools (Zamel, 1983; Field \& Yip, 1992). The textbook's list of markers provides students with a variety of DM that 
Winny Agustia Riznanda: Discourse Markers in Tertiary Level Students' Essay Writing: Ability and Problems $\mid 9$

are categorized based on the pragmatic functions they carry (for example, 'contrastive,' 'adversative,') without the semantic and grammar constraints of each marker. As a result, students assumed that DM can be used interchangeably as long as they are in the same pragmatic category. The absence of explicit instructions on how each DM can carry out different semantic roles in writing appears to confirm student assumptions.

The overuse problem could be caused by one of the following factors. First, this could be due to the writer's perception of his readers. The essay writer may underestimate the readers' knowledge; alternatively, the essay writer assumes that the reader will understand the writer's writing. The author strongly believes that sentences should be linked to linking words in both of these assumptions. The second reason is assumed due to instruction-related issues, in which instructors and textbooks overemphasize the use of DM. The last issue can be caused by essay writers believing that there is a positive relationship between the quality of writing and the number of DM used.

This study indicated that EFL learners encountered difficulties in using DM appropriately in essay writing. In fact, as a requirement for effective writing, the use of DM assists writers in producing coherent texts and effectively communicating with readers. However, due to a lack of DM knowledge, the absence of DM does not always render the text ineffective because the relationship between ideas is implicit or implied in this case. The use of DM makes it clear. Even if the meaning is correctly interpreted, incorrect use of DM can sometimes interfere with the reader's interpretation of the meaning or message. As a result, this phenomenon essentially demonstrates the stage at which students are still improving their ability to write effective essays using DM.

\section{CONCLUSION}

Based on the findings, it is possible to conclude that, while the participants demonstrated an awareness on the use of DM to construct a coherent composition, their ability to use DM appropriately and effectively requires more improvement. To enhance the effectiveness on the use of DM, the following ideas are required to be considered. Teachers or lecturers of English are required to provide clear explanation on the importance of DM since the proper use of DM increases the quality of writing, especially when it comes to academic 
writing. To prevent the issue, the semantic and syntactic constraints of DM and conjunctions must be recognized. Furthermore, students need to be emphasized that DM makes their ideas more understandable. As a result, it is critical for students not to depend too heavily on DM in their writing, but rather on how concepts are neatly and logically interrelated, and to focus on arranging their arguments smoothly and coherently.

\section{REFERENCES}

Aijmer, K. (2002). English Discourse Particles: Evidence from a Corpus. Amsterdam/Philadelphia: John Benjamins. http://dx.doi.org/10.1075/scl.10

Aijmer, K. (2013). Understanding Pragmatic Markers: A Variational Pragmatic Approach. Edinburgh: Edinburgh Unversity Press.

Aijmer, K., \& Simon-Vandenbergen, A. M. (2006). Pragmatic Markers in Contrast. Oxford: Elsevier.

Altenberg, B. (2006). The function of adverbial connectors in the second initial position in English and Swedish. In K. Aijmer, \& A. M. Simon-Vandenbergen (Eds.), Pragmatic Markers in Contrast (pp. 1137). Oxford: Elsevier.

Andersen, E., Brizuela, M., DuPuy, B., \& Gonnerman, L. (1999). Crosslinguistic evidence for the acquisition of discourse markers as register variables. Journal of Pragmatics, 10, 339-351. http://dx.doi.org/10.1016/ S0378-2166(98)00108-8

Andersen, G. (2001). Pragmatic Markers and Sociolinguistic Variation: A Relevance-Theoretic Approach to the Language of Adolescents. Amsterdam/Philadelphia: John Benjamins. http://dx.doi.org/10.1016/s0378- 2166(98)00108-8

Biber, D., Johansson, S., Leech, G., Conrad, S., \& Finegan, E. (1999). Longman grammar of spoken and written English. London: Longman.

Blakemore, D. (1987). Semantic Constraints on Relevance. Oxford: Blackwell.

Blackmore, D. (1992). Understanding Utterances. Oxford: Blackwell. 
Winny Agustia Riznanda: Discourse Markers in Tertiary Level Students' Essay Writing: Ability and Problems|11

Blakemore, D. (2002). Relevance and Meaning: The Semantics and Pragmatics of Discourse Markers. New York: Cambridge University Press. http://dx.doi.org/10.1017/CBO9780511486456

Bolton, K., Nelson G., \& Hung, J. (2002). A corpus-based study of connectors in student writing. Research from the International Corpus of English in Hong Kong (ICE-HK). International Journal of Corpus Linguistics, $\quad 7(2), \quad$ 165-182. Retrieved from http://englishteachersplace.com/wpcontent/uploads/2011/09/ACorpus-based-study-of-connectors-in-studentwriting.pdf.

Brinton, L. J. (1996). Pragmatic Markers in English. Grammaticalization and Discourse Functions. Berlin: Mouton de Gruyter.http://dx.doi.org/10.1515/9783110907582

Brown, H. D. (2007). Teaching by Principles. an Interactive Approach to Language Pedagogy. (3rd ed). New York, NY: Addison Wesley Longman.

Castro, C. (2004). Cohesion and the social construction of meaning in the essays of Filipino college students writing in L2 English.Asia Pacific Education Review, 5(2), 215-225

Celce-Murcia, M. \& Larsen-Freeman, D. (1999). The grammar book (2nd ed.). Michigan: Heinle \& Heinle.

Cho, Y. (1998). Use of connectives in writings by Korean learners of English.

(Report No. ED441348). Retrieved from http://eric.ed.gov/ERICWebPortal/recordDetail?accno=ED441348.

Connor, U. (1984). A study of cohesion and coherence in English as a second language students' writing. Papers in Linguistics: International Journal of Human Communication, 17, 301- 316.

Crossley, A., \& McNamara, S. (2011). Shared features of L2 writing: Intergroup homogeneity and text classification. Journal of Second Language Writing, 20, 271-285. http://dx.doi.org/10.1016/ j.jslw.2011.05.007 
Defazio, J., Jones, J., Tennant, F., \& Hook, S.A. (2010). Academic literacy: The importance and impact of writing across the curriculum - a case study. Journal of the Scholarship of Teaching and Learning, 10(2), pp. $34 \quad$ - 47.4 Retrieved from https://files.eric.ed.gov/fulltext/EJ890711.pdf

Field, Y., \& Yip, L. M. O. (1992). A comparison of internal conjunctive cohesion in the English essay writing of Cantonese speakers and native speakers of English. RELC Journal, 25(1), 15-28

Fischer, K. (2006). Towards an understanding of the spectrum of approaches to discourse particles: Introduction to the volume. In K. Fischer (Ed.), Approaches to Discourse Particles. Oxford: Elsevier

Fraser, B. (1999). What are discourse markers? Journal of Pragmatics, 31(7), 931-952

Granger, S., \& Tyson, S. (1996). Connector usage in English essay writing of native and non-native EFL speakers of English. World Englishes, 15(1), 19-29. http://dx.doi.org/10.1111/j.1467-971X.1996.tb00089.x

Hinkel, E. (2001). Second language writers' text: Linguistic and rhetorical features. Mahwah, NJ: Lawrence Erlbaum.

Halliday, M.A.K.,\& Hasan, R.(1976). Cohesion in English. London, UK: Longman.

Hyland, K. (1998). Exploring corporate rhetoric: Metadiscourse in the CEO's letter. Journal of Business Communication, 2, 224-245. http://dx.doi.org/ 10.1177/002194369803500203

Hyland, K. (2005). Metadiscourse: Exploring Interaction in Writing. London: Continuum.

Jalififar, A. 2008. Discourse markers in composition writing: The case of Iranian learners of English as foreign language teaching. English Language Teaching, 1(2), 114-122.

Johnson, P. (1992). Cohesion and coherence in compositions in Malay and English language. RELC Journal, 23(2), 1-17.

Kao, T.Y.\& Chen, L.M. (2011, November). Diagnozing discoursal organization in learner via conjunctive adverbial. Paper presented at the 23rd Conferenceon Computational Linguistics and Speech Processing, Pittsburgh. 
Winny Agustia Riznanda: Discourse Markers in Tertiary Level Students' Essay Writing: Ability and Problems|13

Kellog, Ronald T. (2008). Training Writing Skills: A Cognitive Developmental Perspective Journal of Writing Research. USA: Department of Psychology, Saint Louis University.

Liu, M., \& Braine, G. (2005). Cohesive features in argumentative writing produced by Chinese undergraduates. System, 33, 623-635.

McCarthy, M. (1993). Discourse analysis for language teachers. Cambridge: Cambridge University Press.

Martinez, C. L. (2004). Discourse markers in the expository writing of Spanish university students. IBERICA, 8, 63-80

Modhish, A. (2012). Use of Discourse Markers in the Composition Writings of Arab EFL Learners. English Language Teaching, 5(5), 56-61.

Müller, S. (2004). Well, you know that type of person: Functions of 'Well' in the speech of American and German students. Journal of Pragmatics, 36(6), 1157-1182.

Narita, M., Sato, C. \& Sugiura, M. (2004). Connector usage in the English essay writing of Japanese EFL learners. Proceedings of the Fourth InternationalConference on Language Resources and Evaluation, 1171-1174. Retrieved from http://gandalf.aksis.uib.no/non/lrec2004/papers.htm

Oktavianti, D., Gusmuliana, P., \& Apriani, E. (2021). The Students' Strategies in Developing Their Ideas in Writing Essay. Jadila: Journal of Development and Innovation in Language and Literature Education, 1(4), 389-406.

Oshima, A., \& Hogue, A. (2006). Writing academic English ( $4^{\text {th }}$ ed.). White Plains, NY: Pearson Education.

Patriana, A.W., Rachmajanti, S., \& Mukminatien, N. Students' ability in using discourse markerso to build coherence in compositions. TEFLIN Journal, 27(2), 2016. Retrieved fromhttp://teflin.org/journal/index.php/journal/article/view/332/270

Quirk, R., Greenbaum, S., Leech, G., \&Svartvik, J. (1985). Comprehensive Grammar of the English language. London: Longman

Rahimi, M. (2011). Discourse markers in argumentative and expository writing of Iranian EFL learners. World Journal of English Language, $1(2), 68-78$. 
Raimes, A. (1983). Techniques in Teaching Writing. Hong Kong: Oxford University Press

Richards, J. C., \& Renandya, W. A. (2002). Methodology in language teaching: An anthology of current practice. Cambridge, UK: Cambridge University Press.

Redeker, G. (1991). Review article: Linguistic markers of discourse structure. Linguistics, $29, \quad 1139-1172$. http://dx.doi.org/10.1515/ling.1991.29.6.1139

Sanjaya, H. K., Apriani, E., \& Edy, S. (2020). Using web blogs in teaching writing for EFL students. Journal of English Education and Teaching (JEET), 4(4), 516-535.

Schiffrin, D. (2001). Discourse markers: language, meaning, and context. In D. Schiffrin, D. Tannen, and H. Hamilton, Handbook of Discourse Analysis (pp. 56-75). Malden: Blackwell Publishers.

Schiffrin, D. (1987). Discourse markers. Cambridge: Cambridge University Press.

Schourup, L. (1999). Discourse Markers. Lingua, 107, 227-265. http://dx.doi.org/10.1016/S0024-3841 (96)90026-1

Schourup, L. (2011). The discourse marker now: A relevance-theoretic approach. Journal of Pragmatics, 43(8), 2120-2129. http://dx.doi.org/10.1016/j.pragma.2011.01.005

Setyowati, L., \& Sukmawan, S. (2013). EFL Indonesian students' attitude toward writing in English. Arab World English Journal, 7(4), pp. 365- $378 . \quad$ Retrieved from https://papers.ssrn.com/sol3/papers.cfm?abstract_id=2898636

Seow, A. (2002). The writing process and process writing. In J. C. Richards \& W. A. Renandya (Eds.), Methodology in language teaching: an anthology of current practice (pp. 315-320). Cambridge: Cambridge University Press

Swan, M. (2005). Practical English Usage. Oxford: Oxford University Press.

Tadayyon, M. (2017). Exploring discourse markers used in academic papers: A comparative corpus-based inquiry of Iranian and English native writers. Iranian EFL Journal. 
Winny Agustia Riznanda: Discourse Markers in Tertiary Level Students' Essay Writing: Ability and Problems|15

Tapper, M.(2005).Connectives in advanced Swedish EFL learners' written English- preliminary results. The Department of English: Working Papers in English Linguistics, 5, 116- 144

Tyler, A., \& Bro, J. (1992). Discourse structure in nonnative English discourse. Studies in Second Language Acquisition, 14(1), 71-86.

White, E. M. (1998). Developing Successful College Writing Programs. Portland, ME: Calendar Islands Publishers

Wei Sun. (2013). The Importance of Discourse Markers in English Learning and Teaching. Theory and Practice in Language Studies, 3 (11), 2136-2140 Williams, J. D. (2014). Preparing to Teach Writing: Research, theory, and practice (4th ed.). NY: Routledge

Zamel, V. (1983). Teaching those missing links in writing. ELT Journal, 37(1), 22-29.

Zhang, M. (2000). Cohesive features in the expository writing of undergraduates in two Chinese universities. RELC Journal, 31(1), $61-95$ 
16 | ENGLISH FRANCA, Vol. 5, No. 1, 2021 